\title{
Evaluation of antiplasmodial activity of medicinal plants from North Indian Buchpora and South Indian Eastern Ghats
}

\author{
Naveen K Kaushik ${ }^{1,3 \dagger}$, Asokan Bagavan ${ }^{2 \dagger}$, Abdul A Rahuman ${ }^{2 *}$, Abdul A Zahir ${ }^{2}$, Chinnaperumal Kamaraj ${ }^{2}$, \\ Gandhi Elango ${ }^{2}$, Chidambaram Jayaseelan², Arivarasan V Kirthi ${ }^{2}$, Thirunavukkarasu Santhoshkumar², \\ Sampath Marimuthu², Govindasamy Rajakumar ${ }^{2}$, Santosh K Tiwari ${ }^{3,4}$ and Dinkar Sahal ${ }^{* *}$
}

\begin{abstract}
Background: Development of resistance against the frontline anti-malarial drugs has created an alarming situation, which requires intensive drug discovery to develop new, more effective, affordable and accessible anti-malarial agents.

Methods: Inspired by their ethnobotanical reputation for being effective against febrile diseases, antiplasmodial potential of ethyl acetate extracts (EAE) and methanol extracts (ME) of 17 medicinal plants collected from the Eastern Ghats of South India and Buchpora, North India were explored against Plasmodium falciparum in vitro using the SYBR Green assay. The results were validated both by confirmation that the fall in fluorescence signal was not due to quenching effects mediated by phytochemical extracts and by Giemsa-stained microscopy.

Results: Using EAE or ME, promising antiplasmodial activity $\left(\mathrm{IC}_{50}\right.$ Pf3D7 $\left.\leq 20 \mu \mathrm{g} / \mathrm{ml}\right)$, was seen in Aerva lanata (Whole aerial parts-EAE), Anisomeles malabarica (Leaf-EAE), Anogeissus latifolia (bark-EAE), Cassia alata (leaves-EAE), Glycyrrhiza glabra (root-EAE), Juglans regia (seed-ME), Psidium guajava (leaf-ME and EAE) and Solanum xanthocarpum (Whole aerial parts-EAE). EAEs from leaves of Couroupita guianensis, Euphorbia hirta, Pergularia daemia, Tinospora cordifolia and Tridax procumbens as also ME from Ricinus communis (leaf and seed) showed good antiplasmodial activity (Pf 3D7 $I C_{50} 21-40 \mu \mathrm{g} / \mathrm{ml}$ ). Moderate activity (Pf 3D7 IC $C_{50}: 40-60 \mu \mathrm{g} / \mathrm{mL}$ ) was shown by the leaf EAEs of Cardiospermum halicacabum, Indigofera tinctoria and Ricinus communis while the remaining extracts showed marginal (Pf 3D7 $I C_{50} 60$ to $\left.>100 \mu \mathrm{g} / \mathrm{ml}\right)$ activities. The promising extracts showed good resistance indices $(0.41-1.4)$ against the chloroquine resistant INDO strain of $P$. falciparum and good selectivity indices ( 3 to $>22.2$ ) when tested against the HeLa cell line.

Conclusion: These results provide validity to the traditional medicinal usage of some of these plants and further make a case for activity-guided purification of new pharmacophores against malaria.
\end{abstract}

\section{Background}

In the absence of a credible vaccine and with emergence of resistance to almost all anti-malarial drugs, the dream of eradication of malaria appears to be a huge challenge. Caused by a protozoan parasite, malaria remains one of the dreaded diseases of the developing world, killing

\footnotetext{
*Correspondence: abdulrahuman6@hotmail.com; dinkar@icgeb.res.in ${ }^{\dagger}$ Equal contributors

2Unit of Nanotechnology and Bioactive Natural Products, Department of Zoology, C. Abdul Hakeem College, Melvisharam 632509, Vellore District, Tamil Nadu, India

'Malaria Research Group, International Centre for Genetic Engineering and Biotechnology, Aruna Asaf Ali Marg, New Delhi 110067, India

Full list of author information is available at the end of the article
}

$367,000-755,000$ people and causing disease in 124-283 million people annually [1]. The most severe manifestations of malaria are caused by Plasmodium falciparum. Even as malaria has been affecting both the economic and emotional aspects of mankind for a long time, the relief against malaria has been coming in the form of herbal treatments, such as cinchona bark and Qing Hao leaves, which gave quinine and artemisinin respectively. The quinoline-based quinine first and chloroquine later proved to be effective therapies against malaria till resistance against quinolines began to surface and spread to large parts of the world [2]. Against this scenario, artemisinin proved to be a smart, fast acting, potent drug

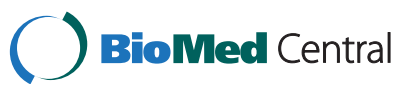

(c) 2015 Kaushik et al.; licensee BioMed Central. This is an Open Access article distributed under the terms of the Creative Commons Attribution License (http://creativecommons.org/licenses/by/4.0), which permits unrestricted use, distribution, and reproduction in any medium, provided the original work is properly credited. The Creative Commons Public Domain Dedication waiver (http://creativecommons.org/publicdomain/zero/1.0/) applies to the data made available in this article, unless otherwise stated. 
against chloroquine-resistant malaria. However, artemisinin resistance in the form of delayed clearance of the parasite is now on the horizon[3] conjuring images of a world where mankind may be left with no effective drug against malaria. This calls for a rigorous search for novel anti-malarials.

One optimistic source for new affordable treatments against malaria lies in the use of traditional herbal remedies. Despite the recent successes in rational drug design and synthetic chemistry techniques by pharmaceutical companies, natural products and particularly medicinal plants have remained an important source of new drugs [4,5]. A definite virtue with medicinal plants is the rich ethnopharmacological history of traditional knowledge and usage associated with them. It is quite possible that their use as nutrients or spices may already be providing a significant degree of protection to people at large against malaria. However if the gist of traditional knowledge can be validated by scientific experiments, affordable and dependable cures can be found against the drug resistant dreaded forms of malaria. Further such exploratory endeavours can pave the path for identifying novel pharmacophores against malaria, which can be chemically synthesized and fine tuned as drugs of the future. With this perspective in mind, here is described the antiplasmodial potential of the extracts of 17 medicinal plants having the reputation of their usage against febrile diseases.

\section{Methods}

Methodology of collection of ethnomedical information

Recommendation of traditional healers and available literature were referred for selection and collection of medicinal plants. Information regarding the pharmacological usage of these plants is given in Additional file 1.

\section{Identification and collection of plant materials}

The seeds of Juglans regia (Juglandaceae) were collected from the Buchpora, Srinagar district, $\left(34^{\circ} 8^{\prime} 14^{\prime \prime} \mathrm{N} 75^{\circ} 2^{\prime} 16^{\prime \prime}\right.$ E, altitude $2743 \mathrm{~m}$ ) of Jammu and Kashmir, North India between October and November 2010 (Figure 1). The leaves of Anisomeles malabarica (Lamiaceae), Psidium guajava (Myrtaceae), Tridax procumbens (Asteraceae), leaves and seeds of Ricinus communis (Euphorbiaceae),

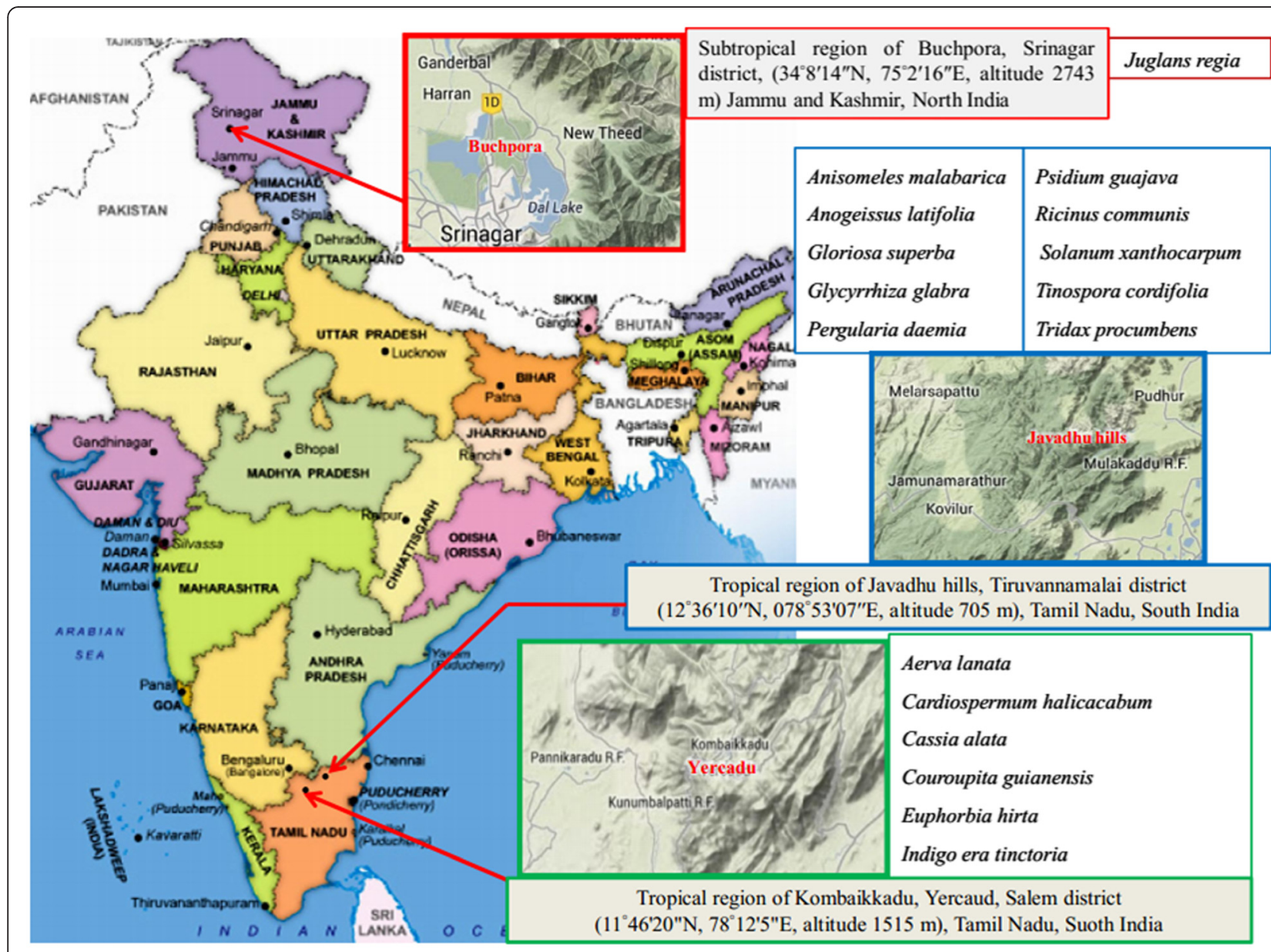

Figure 1 Sites of collection of medicinal plants from North Indian Buchpora and South Indian Eastern Ghats. 
and the flowers of Gloriosa superba (Liliaceae), Pergularia daemia, Tinospora cordifolia, bark of Anogeissus latifolia, root of Glycyrrhiza glabra, and whole aerial parts of Solanum xanthocarpum were collected from the tropical region of Javadhu Hills, Jamunamarathur, Tiruvannamalai district $\left(12^{\circ} 36^{\prime} 10^{\prime \prime} \mathrm{N}, 078^{\circ} 53^{\prime} 07^{\prime \prime} \mathrm{E}\right.$, altitude $705 \mathrm{~m}$ ), Tamil Nadu, South India (Figure 1). The leaves of Cardiospermum halicacabum, Cassia alata, Couroupita guianensis, Euphorbia hirta, Indigofera tinctoria and whole aerial parts of Aerva lanata were collected from the Eastern Ghats, Kombaikkadu, Yercaud, Salem district $\left(11^{\circ} 46^{\prime} 20^{\prime \prime} \mathrm{N}, 78^{\circ} 12^{\prime} 5^{\prime \prime} \mathrm{E}\right.$, altitude $\left.1,515 \mathrm{~m}\right)$, Tamil Nadu, South India. The taxonomic identifications of collected samples were made by Dr. C. Hema, Department of Botany, Arignar Anna Govt. Arts College for Women, Walajapet, Vellore, India, following which the voucher specimens were numbered and kept in laboratory for further reference. During raw material collection, sustainable harvesting was practiced in order to protect the habitat. For each medicinal plant, information about its vernacular name, the part used, preparation, administration and posology was obtained (Additional file 1).

\section{Preparation of crude plant extracts}

The collected plants samples were air-dried for 7-30 days in the shade at the environmental temperatures $\left(27^{\circ} \mathrm{C}-37^{\circ} \mathrm{C}\right)$ and the leaves $(250 \mathrm{~g})$, flowers $(550 \mathrm{~g})$, seeds $(350 \mathrm{~g})$ were powdered mechanically using a commercial electrical stainless steel blender and extracted with a) ethyl acetate (Qualigens) and b) methanol (Qualigens) in a Soxhlet apparatus (boiling point range $60-80^{\circ} \mathrm{C}$ ) for $8 \mathrm{~h}$. Extracts were concentrated on a rotary evaporator under a reduced pressure of 22$26 \mathrm{~mm} \mathrm{Hg}$ at $45^{\circ} \mathrm{C}$ and the residues obtained were weighed and stored at $4^{\circ} \mathrm{C}$.

\section{In vitro cultivation of Plasmodium falciparum}

Chloroquine (CQ)-sensitive strain 3D7 and CQ-resistant strain INDO of Plasmodium falciparum were used for in vitro blood stage culture to test the antiplasmodial efficacy of different plant extracts. The culture was maintained at the Malaria Research Laboratory, International Centre for Genetic Engineering and Biotechnology, New Delhi, India. Plasmodium falciparum culture was maintained according to the method described by Trager and Jensen [6] with minor modifications, in fresh $\mathrm{O}+\mathrm{ve}$ human erythrocytes suspended at 4\% haematocrit in RPMI 1640 (Sigma) containing 0.2\% sodium bicarbonate, 0.5\% albumax I, $45 \mu \mathrm{g} / \mathrm{L}$ hypoxanthine, and $50 \mu \mathrm{g} / \mathrm{L}$ gentamicin and incubated at $37^{\circ} \mathrm{C}$ under a gas mixture of $5 \% \mathrm{O}_{2}$, $5 \% \mathrm{CO}_{2}$, and $90 \% \mathrm{~N}_{2}$. Every day, infected erythrocytes were transferred into fresh complete medium to propagate the culture.

\section{Dilutions of drugs and test samples}

Stock solutions of plant extracts and artemisinin were prepared in dimethyl sulfoxide (DMSO) while CQ stock solution was in water (Milli-Q grade). All stocks were then diluted with culture medium to achieve the required concentrations (in all cases except $C Q$, the final solution contained $0.4 \%$ DMSO, which was found to be non-toxic to the parasite). Drugs and plant extracts were then placed in 96-well flat bottom tissue culture grade plates.

\section{In vitro antiplasmodial assays on Plasmodium falciparum in human red blood cell culture}

The extracts of experimental plants were evaluated for their antiplasmodial activity against 3D7 and INDO strains of $P$. falciparum. For drug screening, SYBR green I-based fluorescence assay was set up as described [7]. Sorbitol synchronized parasites [8] $(100 \mu \mathrm{l})$ were incubated under normal culture conditions at $2 \%$ haematocrit and $1 \%$ parasitaemia in the absence or presence of increasing concentrations of plant extracts. CQ and artemisinin were used as positive controls, while 0.4\% (v/v) DMSO was used as the negative control. After $48 \mathrm{~h}$ of incubation, $100 \mu \mathrm{l}$ of SYBR Green I lysis buffer was added to each well and mixed twice gently with multi-channel pipette and incubated in dark at $37^{\circ} \mathrm{C}$ for $1 \mathrm{~h}$. Fluorescence was measured with a Victor fluorescence multiwell plate reader (PerkinElmer, Waltham, MA) with excitation and emission wavelength bands centered at 485 and $530 \mathrm{~nm}$, respectively. The fluorescence counts were plotted against the drug concentration and the $50 \%$ inhibitory concentration $\left(\mathrm{IC}_{50}\right)$ was determined by analysis of dose response curves. Results were validated microscopically by examination of Giemsa stained smears of extract treated parasite cultures. In view of the fluorescence basis of the SYBR Green assay, it was important to assess artefacts due to quenching effects caused by phytochemicals present in each of the plant extracts tested. To accomplish this, parasite cultures ( $2 \%$ haematocrit and $10 \%$ parasitaemia) were incubated with or without test extracts $(100 \mu \mathrm{g} / \mathrm{ml})$ for $1 \mathrm{hr}$ at $37^{\circ} \mathrm{C}$ following which $100 \mu \mathrm{l}$ of SYBR green lysis buffer was added and further incubated in dark at $37^{\circ} \mathrm{C}$ for $1 \mathrm{~h}$. Fluorescence was measured with a Victor fluorescence multi-well plate reader with excitation and emission wavelength bands centered at 485 and $530 \mathrm{~nm}$, respectively. Fluorescence of treated and untreated cultures was compared to detect quenching effects.

\section{Cytotoxic activity on HeLa cells using MTT assay}

The cytotoxic effects of extracts on host cells were assessed by functional assay as described in ref [9] using HeLa cells cultured in RPMI containing 10\% foetal bovine serum, $0.21 \%$ sodium bicarbonate (Sigma) and 
$50 \mu \mathrm{g} / \mathrm{mL}$ gentamicin (complete medium). Briefly, cells $\left(10^{4}\right.$ cells/200 $\mu \mathrm{l} /$ well $)$ were seeded into 96 - well flatbottom tissue culture plates in complete medium. Drug solutions were added after $24 \mathrm{~h}$ of seeding and incubated for $48 \mathrm{~h}$ in a humidified atmosphere at $37^{\circ} \mathrm{C}$ and $5 \%$ $\mathrm{CO}_{2}$. DMSO (as positive inhibitor) was added at $10 \% \mathrm{v} / \mathrm{v}$. Twenty micro liters of a stock solution of MTT $(5 \mathrm{mg} / \mathrm{mL}$ in $1 \mathrm{X}$ phosphate buffered saline) was added to each well, gently mixed and incubated for another $4 \mathrm{~h}$. After spinning the plate at $1,500 \mathrm{RPM}, 30^{\circ} \mathrm{C}$ for $5 \mathrm{~min}$, supernatant was removed and $100 \mu \mathrm{l}$ of DMSO (stop agent) was added. Formation of formazan was read on a microtiter plate reader (VersaMax Microplate Reader, Molecular Devices, USA) at $570 \mathrm{~nm}$. The $50 \%$ cytotoxic concentration $\left(\mathrm{TC}_{50}\right)$ of test samples was determined by analysis of dose-response curves. Therapeutic index was calculated as a ratio of $\mathrm{TC}_{50} \mathrm{HeLa} / \mathrm{IC}_{50} 3 \mathrm{D} 7$.

\section{Results and discussion}

Indigenous healthcare systems have always played a vital role in the management of community health and discovery of novel chemotherapeutic agents. Medicinal plants which offer a wide diversity of medicinal properties have proved to be a boon for malaria therapy as two of the most important anti-malarial drugs, namely quinine and artemisinin, have their origins in the medicinal plants Cinchona officinalis and Artemisia annua, respectively. Ethnomedicinal plants could be attractive start materials as they are wide spread and also a large population relies on them for their curative effects. In the present study, 17 medicinal plants known for their traditional medicinal usage (Additional file 1) and pharmacological activities (Additional file 2) were evaluated for (a) their antiplasmodial activity against CQ-sensitive $P$. falciparum 3D7 and CQ-resistant P. falciparum INDO strains and (b) their toxicity against HeLa cell line (Table 1). Among the seventeen plants studied, seven (Aerva lanata, Anisomeles malabarica, Anogeissus latifolia, Couroupita guianensis, Indigofera tinctoria, Juglans regia and Solanum xanthocarpum) have been tested for their antiplasmodial activity against both the 3D7 and INDO strains for the first time. As shown in Figure 2 and Table 1, five of these seven plants showed promising (Pf3D7 $\mathrm{IC}_{50} 6 \mu \mathrm{g} / \mathrm{ml}$ to $20 \mu \mathrm{g} / \mathrm{ml}$ ) antiplasmodial activity. Interestingly four of these plant extracts showed greater potency against the CQ-resistant INDO strain than against the CQ-sensitive 3D7 strain. Further the selectivity indices (HeLa cells versus $P$. falciparum) for the promising extracts ranged from 3 to $>22$ (Table 1).

For the remaining ten plants, which have been studied for antiplasmodial activity by previous investigators, experiments were performed to find which part of plant and solvent of extraction could contribute phytochemicals with superior antiplasmodial activity. In this context, leaf methanol and ethyl acetate extracts of Psidium guajava were found to show promising antiplasmodial activity ( $\mathrm{IC}_{50}$ Pf3D7: 15 \& $12.5 \mu \mathrm{g} / \mathrm{ml}$ respectively) (Table 1, Figure 2). Earlier Nundkumar and Ojewole [10] have reported promising activity of aqueous stem-bark extract of Psidium guajava against CQ-sensitive P. falciparum D10 strain $\left(\mathrm{IC}_{50}: 20 \mu \mathrm{g} / \mathrm{ml}\right)$. This suggests that Psidium guajava leaves could be a better source for antiplasmodial molecules than stem-bark since leaves are renewable while girding for stem bark can cause severe injury to the tree.

Methanol extracts of seed and leaf of Ricinus communis ( $\mathrm{IC}_{50}$ Pf3D7: $30 \& 34 \mu \mathrm{g} / \mathrm{ml}$ respectively) showed good antiplasmodial activity. However the corresponding ethyl acetate extracts (IC50 Pf $3 \mathrm{D} 7>71 \mu \mathrm{g} / \mathrm{ml}$ ) showed moderate to poor antiplasmodial activity (Table 1, Figure 2). Clarkson et al. [11] also reported similar moderate activity ( $\mathrm{IC}_{50}$ P. falciparum D10: $27.5 \mu \mathrm{g} / \mathrm{ml}$ ) in $R$. communis leaves DCM-methanol extract whereas they reported promising activity in its stem dichloromethane/methanol extract ( $\mathrm{IC}_{50}$ P. falciparum D10: $8 \mu \mathrm{g} / \mathrm{ml}$ ).

Leaf ethyl acetate extract of Tridax procumbens showed good activity $\left(\mathrm{IC}_{50}\right.$ 3D7: $32 \mu \mathrm{g} / \mathrm{ml}$ ) whereas the corresponding methanol extract showed moderate antiplasmodial activity $\left(\mathrm{IC}_{50} 3 \mathrm{D} 7: 62 \mu \mathrm{g} / \mathrm{ml}\right.$ ) (Table 1, Figure 2). However Appiah-Opong et al. [12] reported poor antiplasmodial activity in whole plant extracts (water, ethanol, chloroform and ethyl acetate) ( $\left.\mathrm{IC}_{50}: 140-430 \mu \mathrm{g} / \mathrm{ml}\right)$. This suggests that leaves should be preferred over the whole plant and extraction should be made in ethyl acetate for enriching antiplasmodial molecules.

Ethyl acetate flower extract of Gloriosa superba showed moderate $\left(\mathrm{IC}_{50} 3 \mathrm{D} 7: 62 \mu \mathrm{g} / \mathrm{ml}\right)$ antiplasmodial activity whereas corresponding methanol extract was found to be inactive up to $100 \mu \mathrm{g} / \mathrm{ml}$ (Table 1 and Figure 2). Bagavan et al. [13] have reported that ethyl acetate and methanol extracts of the leaves of Gloriosa superba have good antiplasmodial effect against CQ resistant strain of P. falciparum INDO $\left(\mathrm{IC}_{50}: 30-40 \mu \mathrm{g} / \mathrm{ml}\right)$ which suggests that leaves of Gloriosa superba may be preferred over its flowers as a source of antiplasmodial molecules.

Cardiospermum halicacabum also known as the balloon plant is a climbing plant widely distributed in tropical and subtropical Africa and Asia. As shown in Figure 2 and Table 1, the leaves ethyl acetate extract of this plant was found to have moderate antiplasmodial activity $\left(\mathrm{IC}_{50}\right.$ Pf3D7: $42 \mu \mathrm{g} / \mathrm{mL}$ ). Clarkson et al. [11] reported that the dichloromethane / methanol (1:1) whole balloon plant extract showed good in vitro antiplasmodial activity (P. falciparum D10 $\mathrm{IC}_{50}: 20 \mu \mathrm{g} / \mathrm{mL}$ ) whereas Waako et al. [14] extracted its shoots with different solvents and reported moderate to poor activity in ethyl acetate (P. falciparum D10 IC $50: 28 \mu \mathrm{g} / \mathrm{mL}$ ) and methanol extracts (P. falciparum D10 $\mathrm{IC}_{50}: 62 \mu \mathrm{g} / \mathrm{mL}$ ). This comparative study suggests that the stem of Cardiospermum 
Table 1 Antiplasmodial activity, Cytotoxicity and selectivity of methanol (M) and ethyl acetate (EA) extracts of selected medicinal plants

\begin{tabular}{|c|c|c|c|c|c|c|}
\hline \multirow{2}{*}{$\begin{array}{l}\text { Sr } \\
\text { No. }\end{array}$} & \multirow[t]{2}{*}{ Name of the plants } & \multirow{2}{*}{$\begin{array}{l}\text { Parts and Solvent of } \\
\text { Extraction M-Methanol } \\
\text { EA-Ethyl acetate }\end{array}$} & \multirow[t]{2}{*}{ Yields (\%) } & \multicolumn{2}{|c|}{ P. falciparum $\mathrm{IC}_{50}(\mu \mathrm{g} / \mathrm{mL})$} & \multirow{2}{*}{$\begin{array}{l}\text { Cytotoxicity }\left(\mathrm{TC}_{50} \mu \mathrm{g} / \mathrm{mL}\right. \\
\text { against HeLa cell line }\end{array}$} \\
\hline & & & & $3 \mathrm{D7}$ & INDO & \\
\hline 1 & Aerva lanata & Whole aerial EA & 15.4 & 17 & $8(0.47)^{*}$ & $77(9.63)^{\#}$ \\
\hline \multirow[t]{2}{*}{2} & Anisomeles malabarica & Leaf M & & $>100$ & - & - \\
\hline & & Leaf EA & & 16 & $16(1)$ & $48(3)^{\#}$ \\
\hline 3 & Anogeissus latifolia & Bark EA & 12.5 & 8 & $4.5(0.56)$ & $>100(>22)$ \\
\hline 4 & $\begin{array}{l}\text { Cardiospermum } \\
\text { halicacabum }\end{array}$ & Leaves EA & 10.2 & 42 & - & - \\
\hline 5 & Cassia alata & Leaves EA & 14.1 & 18 & $20(1.11)$ & $100(5)$ \\
\hline 6 & Couroupita guianensis & Leaves EA & 7.6 & 39 & - & - \\
\hline 7 & Euphorbia hirta & Leaves EA & 9.6 & 21 & - & - \\
\hline \multirow[t]{2}{*}{8} & Gloriosa superba & Flower M & & $>100$ & - & - \\
\hline & & Flower EA & & 62 & - & - \\
\hline 9 & Glycyrrhiza glabra & Root EA & 13.2 & 6 & $4.5(0.75)$ & $22(4.89)$ \\
\hline 10 & Indigofera tinctoria & Leaves EA & 8.5 & 57 & - & - \\
\hline \multirow[t]{2}{*}{11} & Juglans regia & Seed M & & 20 & $12.5(0.625)$ & $>100(>8)$ \\
\hline & & Seed EA & & $>100$ & - & - \\
\hline 12 & Pergularia daemia & Leaves EA & 12.9 & 21 & - & - \\
\hline \multirow[t]{2}{*}{13} & Psidium guajava & Leaf M & & 15 & $9(0.6)$ & $68(4.6)$ \\
\hline & & Leaf EA & & 12.5 & $18(1.4)$ & $82(6.6)$ \\
\hline \multirow[t]{4}{*}{14} & Ricinus communis & Leaf M & & 34 & - & - \\
\hline & & Leaf EA & & 57.5 & - & - \\
\hline & & Seed M & & 30 & - & - \\
\hline & & Seed EA & & 100 & - & - \\
\hline 15 & Solanum xanthocarpum & Whole aerial EA & 11.6 & 17 & $7(0.41)$ & $75(10.7)$ \\
\hline 16 & Tinospora cordifolia & Leaves EA & 6.8 & 31 & - & - \\
\hline \multirow[t]{4}{*}{17} & Tridax procumbens & Leaf M & & 62 & - & - \\
\hline & & Leaf EA & & 32 & - & - \\
\hline & Chloroquine & & & 0.021 & $0.258(12.28)$ & $>200$ \\
\hline & Artemisinin & & & 0.0045 & $0.0045(1)$ & $>200$ \\
\hline
\end{tabular}

$(-)$ not tested, *values in parentheses represent resistance indices $\left(\mathrm{IC}_{50} \mathrm{INDO} / \mathrm{IC} \mathrm{C}_{50} 3 \mathrm{DD}\right)$, " values in parentheses represent selectivity indices $\left(T C_{50}\right.$ HeLa/IC $\left.\mathrm{I}_{50} \mathrm{INDO}\right)$.

halicacabum may have more potent antiplasmodial molecules which makes shoots ethyl acetate extract more potent than leaves ethyl acetate extract.

Cassia alata is an important medicinal as well as an ornamental flowering plant of subfamily Caesalpinioideae. The results described here indicate promising antiplasmodial activity in the ethyl acetate extract of $C$. alata against both CQ sensitive 3D7 $\left(\mathrm{IC}_{50}: 18 \mu \mathrm{g} / \mathrm{mL}\right)$ and $\mathrm{CQ}$ resistant INDO ( $\mathrm{IC}_{50}: 20 \mu \mathrm{g} / \mathrm{mL}$ ) strains with low toxicity to HeLa cells $\left(\mathrm{TC}_{50}: 100 \mu \mathrm{g} / \mathrm{mL}\right)$. However, Zirihi et al. [15] found no antiplasmodial activity up to $50 \mu \mathrm{g} / \mathrm{mL}$ in leaf ethanol extract of Cassia alata whereas Kayembe et al. [16] reported promising antiplasmodial activity $\left(\mathrm{IC}_{50}: 12.5 \mu \mathrm{g} / \mathrm{mL}\right.$ ) in the seed ethanol extract of Cassia alata. This suggests that ethyl acetate is a better solvent for extraction of promising molecules from leaves compared to ethanol whereas ethanol is equally good in their extraction from seeds.

Euphorbia hirta is a pantropical weed, native to India. It is a hairy herb that grows in open grasslands, roadsides and pathways. It is widely used as a medicinal herb in most places it grows (Additional file 1). In the present study, good antiplasmodial activity $\left(\mathrm{IC}_{50}\right.$ Pf3D7: $21 \mu \mathrm{g} /$ $\mathrm{mL}$ ) has been found in leaves ethyl acetate extract of Euphorbia hirta. However, Tona et al. [17] who studied the ethanol, petroleum ether and isoamyl alcohol extracts of Euphorbia hirta whole plant have reported promising antiplasmodial activity $\left(\mathrm{IC}_{50}: 2.4,1.2\right.$ and $2.6 \mu \mathrm{g} / \mathrm{mL}$ respectively). This indicates the importance of solvents and choice of plant parts towards enriching promising metabolites. 


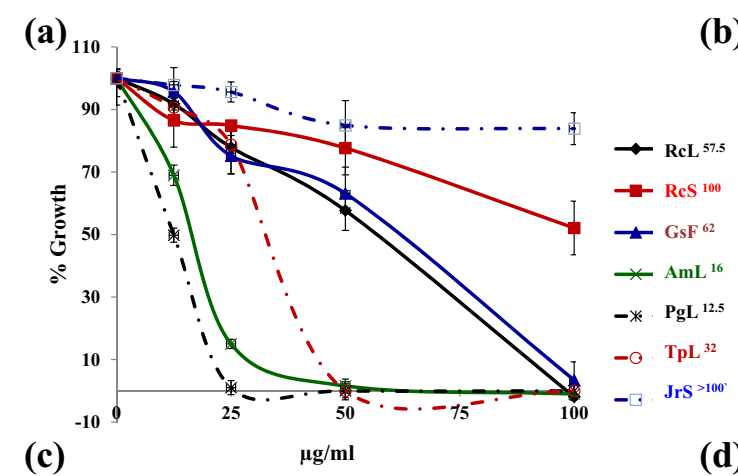

(b)

(c)

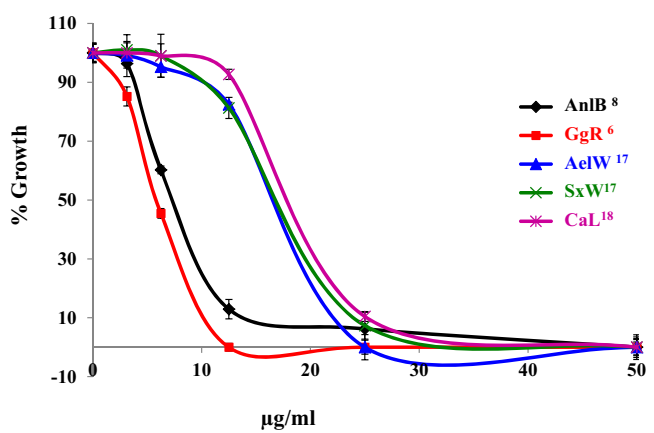

$$
\text { (b) }
$$
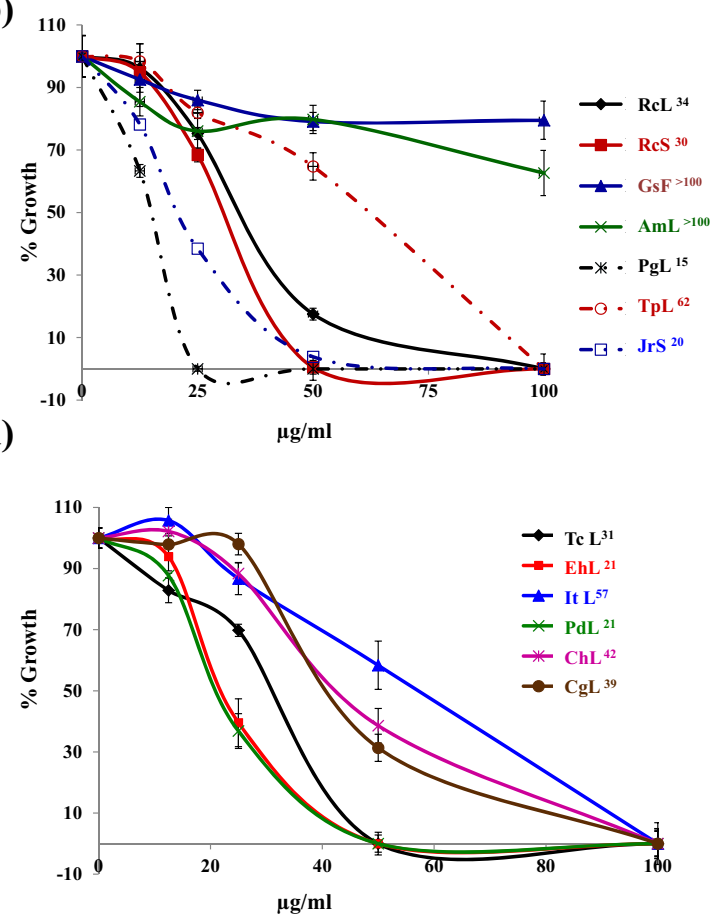

Figure 2 Dose dependent growth inhibition curves of Plasmodium falciparum 3D7 by plant extracts. (a) ethyl acetate extracts and (b) methanol extracts of Ricinus communis leaf (RcL), Ricinus communis seed (RcS), Gloriosa superba flower (GsF), Anisomeles malabarica leaf (AmL), Psidium guajava leaf (PgL), Tridax procumbens leaf (TpL) and Juglans regia seed (JrS). c) ethyl acetate extracts of Anogeissus latifolia Bark (An|B), Glycyrrhiza glabra Roots (GgR), Aerva lanata whole aerial part (AelW), Solanum xanthocarpum whole aerial part (SxW), Cassia alata leaves (CaL) and d) ethyl acetate extracts of Tinospora cordifolia leaves (TCL), Euphorbia hirta leaves (Eh), Indigofera tirictoria leaves (ItL), Pergularia daemia leaves (PdL), Cardiospermum helicacabum leaves $(\mathrm{ChL})$ and Couroupita guianensis leaves $(\mathrm{CgL})$. Superscript numbers in label index refer to $\mathrm{IC} \mathrm{C}_{50}(\mu \mathrm{g} / \mathrm{mL})$.

Glycyrrhiza glabra (liquorice) is a herb belonging to the pea and bean family, and is cultivated for its underground stems that are used to flavour confectionery. In the present study, the roots of this plant were found to have promising anti-plasmodial activity against both 3D7 and INDO strains $\left(\mathrm{IC}_{50}: 6 \& 4.5 \mu \mathrm{g} / \mathrm{mL}\right)$. Prior reports indicate that methanol extract [18] of its aerial parts exhibits poor antiplasmodial activity against CQ sensitive 3D7 $\left(\mathrm{IC}_{50}:>64 \mu \mathrm{g} / \mathrm{mL}\right)$ and good activity against the CQ resistant $\mathrm{K} 1\left(\mathrm{IC}_{50}: 17.5 \mu \mathrm{g} / \mathrm{mL}\right)$ strain of $P$. falciparum. The results reported here suggest that roots may be better source for antiplasmodial molecules than the aerial part of the plant.

Pergularia daemia is a hispid, perennial vine of Apocynaceae family, with an extensive range in the Old World tropics and subtropics. It has been used traditionally to treat a number of ailments (Additional file 1). Kantamreddi and Wright [19] studied the leaves methanol extract of Pergularia daemia against 3D7 and K1 strains of $P$. falciparum and indicated it to be poorly antiplasmodial $\left(\mathrm{IC}_{50}: 203.8\right.$ and $244.1 \mu \mathrm{g} / \mathrm{mL}$, respectively). However in the present study, extraction of leaves with ethyl acetate resulted in about 10-fold potentiation of antiplasmodial activity $\left(P f 3 D 7 \mathrm{IC}_{50}: 21 \mu \mathrm{g} / \mathrm{mL}\right)$ reiterating the crucial role of solvents in extraction of metabolites that hold promise.

Tinospora cordifolia is used in the Indian Ayurvedic system of medicine for the treatment of jaundice, diabetes, and rheumatoid arthritis, and is also used as an immunostimulant. Simonsen et al. [20] reported that the stem ethanol extract of Tinospora cordifolia is poorly antiplasmodial $\left(\mathrm{IC}_{50}\right.$ Pf3D7: $\left.62 \mu \mathrm{g} / \mathrm{mL}\right)$. However, Tran et al. [21] have reported that the stem methanol and methanol : water (1:1) extracts with $\mathrm{IC}_{50} 6.1$ and $3.2 \mu \mathrm{g} /$ $\mathrm{mL}$, respectively against FCR-3 strain of $P$. falciparum possessed promising antiplasmodial activity. In the present study it was found that ethyl acetate leaf extract of Tinospora cordifolia is moderately antiplasmodial (Pf3D7IC $50: 31 \mu \mathrm{g} / \mathrm{mL}$ ) against 3D7 strain of P. falciparum.

Promising extracts $\left(P f 3 \mathrm{D} 7 \mathrm{IC}_{50}:<20 \mu \mathrm{g} / \mathrm{mL}\right)$ of Aerva lanata, Anisomeles malabarica, Anogeissus latifolia, Cassia alata, Glycyrrhiza glabra, Juglans regia, Psidium guajava and Solanum xanthocarpum on further analysis against chloroquine resistant INDO strain also showed good resistance indices $(0.41-1.4)$ suggesting that they may be equally effective against both chloroquine-sensitive and 
(a)

(b)

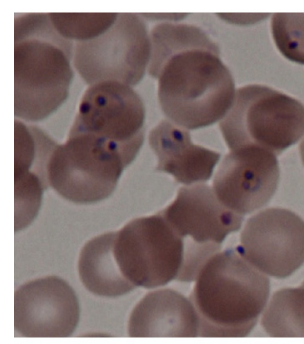

Control
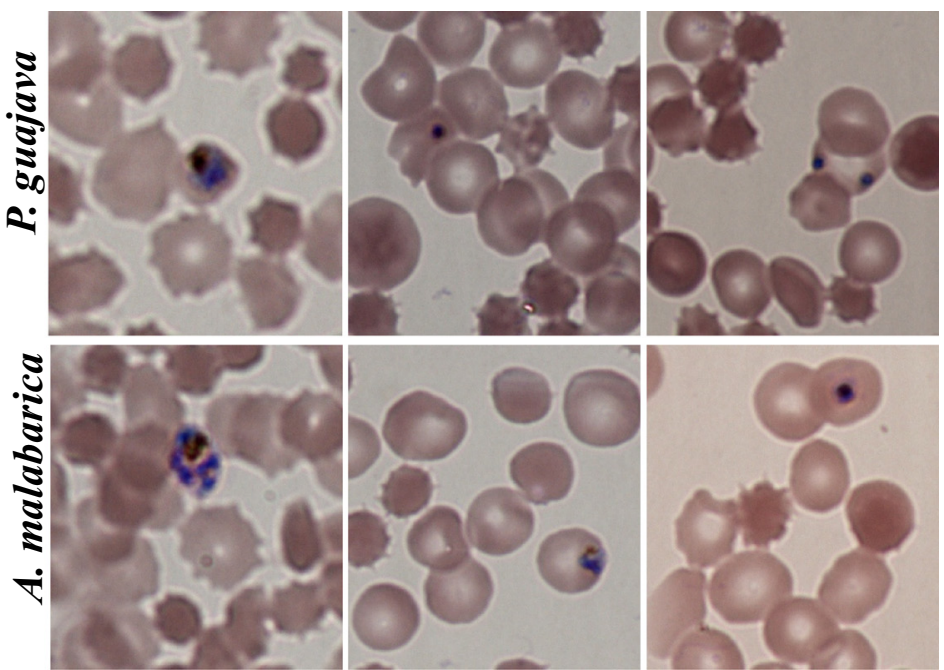

$25 \mu \mathrm{g} / \mathrm{ml}$

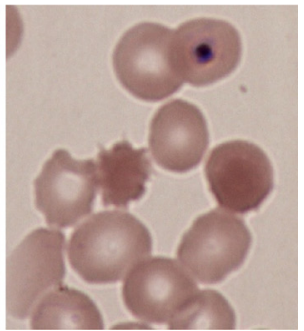

$12.5 \mu \mathrm{g} / \mathrm{ml}$

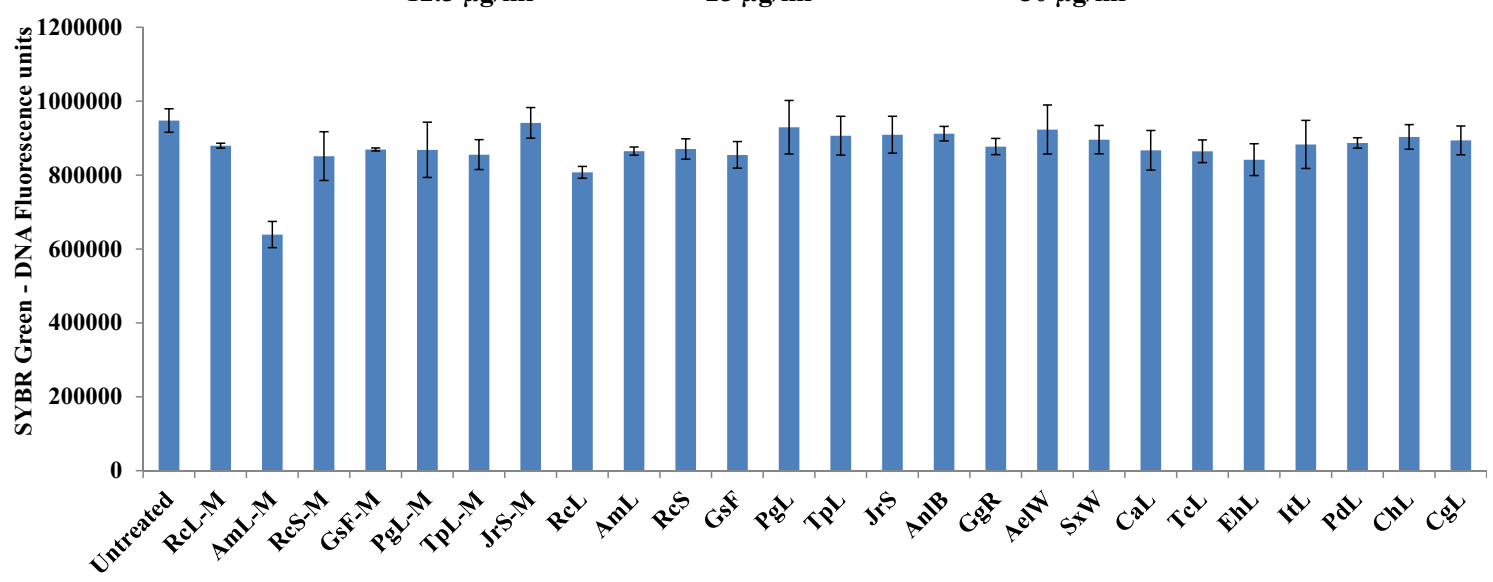

Figure 3 Validation of SYBR Green results by Microscopy and estimation of quenching of fluorescence by plant extracts. (a) Micrographs of synchronized ring stage parasite cultures treated with ethyl acetate extract of Anisomeles malabarica leaf and Psidium guajava leaf after $48 \mathrm{~h}$. Note that at $12.5 \mathrm{\mu g} / \mathrm{ml}$, the parasitemia is decreased and the parasite is arrested at trophozoite stage in case of Pg while the arrest in case of Am is at early schizont stage. (b) Examination of fluorescence quenching effects in plant extracts: Untreated and extract treated (100 $\mu \mathrm{g} / \mathrm{ml})$ parasite cultures (10\% parasitemia) were subjected to SYBR Green fluorescence intensity measurements. The nearly identical intensities across untreated control and extract treated test samples indicate that the test extracts showed no significant quenching of SYBR green 1-DNA fluorescence.

resistant-strains of Plasmodium. Further the selectivity indices of 3 to $>22.2$ observed with some of the plant extracts studied by us suggest that they exhibit considerable selectivity against the malaria parasite over the mammalian HeLa cell line (Table 1).

The results of SYBR Green assay described above were further validated by microscopy and experimental estimation of SYBR Green fluorescence in parasitized red blood cells in presence $v s$ absence of the plant extracts studied here (Figure 3). Microscopic evaluation of ethyl acetate extracts of Anisomeles malabarica and Psidium guajava showed dose dependent inhibition of parasite growth (Figure 3a). Further none of twenty five extracts studied by us showed any significant quenching effects at $100 \mu \mathrm{g} / \mathrm{ml}$ (Figure $3 \mathrm{~b}$ ) providing validity to the SYBR Green assay based results described above.
These results indicate a possible explanation of the traditional use of some of these medicinal plants against malaria or malaria like conditions. These results are significant since they report for the first time broad spectrum antiplasmodial activities in the extracts of Aerva. lanata, Anisomeles malabarica, Anogeissus latifolia, Cassia alata, Couroupita guianensis, Glycyrrhiza glabra, Indigofera tinctoria Juglans regia, Psidium guajava and Solanum xanthocarpum. Further both plant parts and preferred solvents were identified that provide extracts of high antiplasmodial potency. This paves the paths for (a) standardized plant extracts based therapy against malaria and (b) for antiplasmodial activity guided isolation of new pharmacophores and their subsequent development towards phytochemical based novel drugs against malaria. 


\section{Additional files}

Additional file 1: Medicinal properties of selected plant species. Additional file 2: Ethnobotanical exploration and biological activity of selected medicinal plants.

\section{Competing interests}

The authors declare that they have no competing interests.

\section{Authors' contributions}

AB Collected the plant material, AAZ, CK, GE, CJ, AVK, TS, SM, GR prepared the plant extracts. NKK carried out the biological assays, AAR, DS, SKT participated in the design of the study and performed the statistical analysis. NKK, AB, SKT, AAR, DS participated in manuscript drafting. All authors read and approved the final manuscript.

\section{Acknowledgements}

All traditional healers and herborists are highly acknowledged for sharing their indigenous medicinal knowledge on plants and help rendered during the field work. NKK thanks ICMR, New Delhi for Senior Research Fellowship. NKK and DS thank MR4 who generously provided the Chloroquine resistant INDO strain used in the study. Thanks to X. Su who deposited this strain with MR4. AB, AAR, AAZ, CJ, CK, GE and AVK are grateful to Zoology Department, C. Abdul Hakeem of the College for providing the facilities to carry out this work. Asokan Bagavan gratefully thanks University Grants Commission, (F.No.35-71/2008 SR) Government of India, New Delhi for Junior Research Fellowship.

\section{Author details}

${ }^{1}$ Malaria Research Group, International Centre for Genetic Engineering and Biotechnology, Aruna Asaf Ali Marg, New Delhi 110067, India. ${ }^{2}$ Unit of Nanotechnology and Bioactive Natural Products, Department of Zoology, C. Abdul Hakeem College, Melvisharam 632509, Vellore District, Tamil Nadu, India. ${ }^{3}$ Department of Bioscience \& Biotechnology, Banasthali University, P.O. Banasthali Vidyapith, Rajasthan 304 022, India. ${ }^{4}$ Present address: Department of Genetics, Maharshi Dayanand University, Rohtak, Haryana 124001, India.

Received: 16 April 2014 Accepted: 15 January 2015

Published online: 07 February 2015

\section{References}

1. WHO. World Malaria Report. 2014. http://www.who.int/malaria/media/ world_malaria_report_2014/en/.

2. CDC Malaria. Drug Resistance in the Malaria-Endemic World. (Updated Nov 9, 2012) http://mww.cdc.gov/malaria/malaria_worldwide/reduction/drug_resistance.html.

3. White NJ. Counter perspective: artemisinin resistance: facts, fears, and fables. Am J Trop Med Hyg. 2012:87:785.

4. Kaushik NK, Bagavan A, Rahuman AA, Mohanakrishnan D, Kamaraj C, Elango $G$, et al. Antiplasmodial potential of selected medicinal plants from eastern Ghats of South India. Exp Parasitol. 2013;134:26-32.

5. Lombardino JG, Lowe 3rd JA. The role of the medicinal chemist in drug discovery-then and now. Nat Rev Drug Discov. 2004;3:853-62.

6. Trager W, Jensen JB. Human malaria parasites in continuous culture. Science. 1976;193:673-5.

7. Smilkstein M, Sriwilaijaroen N, Kelly JX, Wilairat P, Riscoe M. Simple and inexpensive fluorescence-based technique for high-throughput antimalarial drug screening. Antimicrob Agents Chemother. 2004;48:1803-6.

8. Lambros C, Vanderberg JP. Synchronization of Plasmodium falciparum erythrocytic stages in culture. J Parasitol. 1979;65:418-20.

9. Mosmann T. Rapid colorimetric assay for cellular growth and survival: application to proliferation and cytotoxicity assays. J Immunol Methods. 1983;65:55-63.

10. Nundkumar N, Ojewole JA. Studies on the antiplasmodial properties of some South African medicinal plants used as antimalarial remedies in Zulu folk medicine. Methods Find Exp Clin Pharmacol. 2002;24:397-401.

11. Clarkson C, Maharaj VJ, Crouch NR, Grace OM, Pillay P, Matsabisa MG, et al. In vitro antiplasmodial activity of medicinal plants native to or naturalised in South Africa. J Ethnopharmacol. 2004;92:177-91.

12. Appiah-Opong R, Nyarko AK, Dodoo D, Gyang FN, Koram KA, Ayisi NK. Antiplasmodial activity of extracts of Tridax procumbens and
Phyllanthus amarus in in vitro Plasmodium falciparum culture systems. Ghana Med J. 2011;45:143-50.

13. Bagavan A, Rahuman AA, Kaushik NK, Sahal D. In vitro antimalarial activity of medicinal plant extracts against Plasmodium falciparum. Parasitol Res. 2011;108:15-22.

14. Waako PJ, Gumede B, Smith P, Folb PI. The in vitro and in vivo antimalarial activity of Cardiospermum halicacabum L. and Momordica foetida Schumch. Et Thonn. J Ethnopharmacol. 2005;99:137-43.

15. Zirihi GN, Mambu L, Guede-Guina F, Bodo B, Grellier P. In vitro antiplasmodial activity and cytotoxicity of 33 West African plants used for treatment of malaria. J Ethnopharmacol. 2005;98:281-5.

16. Kayembe J, Taba K, Ntumba K, Tshiongo M, Kazadi T. In vitro anti-malarial activity of 20 quinones isolated from four plants used by traditional healers in the Democratic Republic of Congo. J Med Plant Res. 2010;4:991-4.

17. Tona L, Cimanga RK, Mesia K, Musuamba CT, De Bruyne T, Apers S, et al. In vitro antiplasmodial activity of extracts and fractions from seven medicinal plants used in the Democratic Republic of Congo. J Ethnopharmacol. 2004;93:27-32.

18. Esmaeili S, Naghibi F, Mosaddegh M, Sahranavard S, Ghafari S, Abdullah NR. Screening of antiplasmodial properties among some traditionally used Iranian plants. J Ethnopharmacol. 2009;121:400-4

19. Kantamreddi VS, Parida S, Kommula SM, Wright CW. Phytotherapy used in Orissa state, India for treating malaria. Phytother Res. 2009;23:1638-41.

20. Simonsen HT, Nordskjold JB, Smitt UW, Nyman U, Palpu P, Joshi P, et al. In vitro screening of Indian medicinal plants for antiplasmodial activity. J Ethnopharmacol. 2001;74:195-204.

21. Tran QL, Tezuka Y, Ueda JY, Nguyen NT, Maruyama Y, Begum K, et al. In vitro antiplasmodial activity of antimalarial medicinal plants used in Vietnamese traditional medicine. J Ethnopharmacol. 2003;86:249-52.

\section{Submit your next manuscript to BioMed Central and take full advantage of:}

- Convenient online submission

- Thorough peer review

- No space constraints or color figure charges

- Immediate publication on acceptance

- Inclusion in PubMed, CAS, Scopus and Google Scholar

- Research which is freely available for redistribution

Submit your manuscript at www.biomedcentral.com/submit
C) BioMed Central 